\title{
Critical Discourse Analysis of Additional Information in Skincare Products
}

\author{
Burhanudin Rais', Suhardi², Rr. Putri Intan Permata Sari ${ }^{3}$ \\ ${ }^{1,2}$ Applied Linguistic Program, Universitas Negeri Yogyakarta, Yogyakarta, Indonesia \\ ${ }^{3}$ English Teacher, Primary School Cangkringan 2, Yogyakarta, Indonesia \\ Email: burhanudinrais.2018@student.uny.ac.id ${ }^{1}$
}

Submitted: 05/02/2020

Revised: 11/02/2020

Accepted: $25 / 02 / 2020$

Abstract. Research that analyses critically on claims and additional information on a skincare product is a research that bring the novelty in critical discourse analysis, because the previous study focused on the advertisement or the packaging. Although most skincare products apply this method (using claims and additional information), researchers focus on one of the branded skincare products; Pond's. The main reason is; this product is already widely known and used by the people in Indonesia. Trough critical discourse analysis model from van Dijk, the researchers discuss three dimensions (text, social cognition and social context) in claims and additional information in some products from Pond's. There are seven Pond's products as the data in this study. Besides, researchers used additional data in the form of a survey to five skincare products users. The results of the analysis are; (1) on the text dimension, the general aim is to attract the consumers to choose Pond's as their skincare products. (2) In social cognition, company show marketing techniques that try to obscure the facts in additional information by using small and separated text. (3) In the social context, the influence of consumers who are easily attracted to a product because of the interesting slogan text makes Pond's use the hyperbole language.

Keywords: Critical Discourse Analysis, Text Structure, Social Cognition, Social Dimensions

https://ojs.unm.ac.id/eralingua

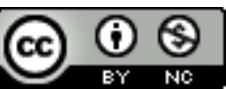

This work is licensed under a Creative Commons Attribution-NonCommercial 4.0 International License 


\section{INTRODUCTION}

Discourse generally defined as everything beyond the sentence (Schiffrin, Tannen, \& Hamilton, 2001). Another definition of discourse says that it is a series of languages or speech that forms meaning and it cannot be separated from the context and situation (Darma, 2009); it means that the context cannot be released in understanding a discourse. Discourse is not only in the form of text because discourse can also be in the form of signs, or symbol that are meaningful in the language (Darma, 2009). Thus, it can be the form of traffic signs, trumpet sounds, or pictures that the meaning is understood along with the context.

Discourse is one of the areas of linguistic studies. Different from the discourse analysis; which only focuses on the text, signs, or symbol, critical discourse analysis also examines the background that underlies the creation of a text, signs, or symbol (Darma, 2009). Besides, critical discourse analysis is a multidisciplinary study; it means that critical discourse analysis is not only focused on one scope of the study (van Dijk, 1993). He added that the analysis of critical discourse reveals the power and domination of a group or institution and social inequality. Thus, the critical discourse analysis proposed by van Dijk has a domain in three dimensions, that is text, social cognition and context (Eriyanto, 2015). These three dimensions are an integral part and carried out together in van Dijk's analysis (Eriyanto, 2015). Thus, the analysis model is described as follows.

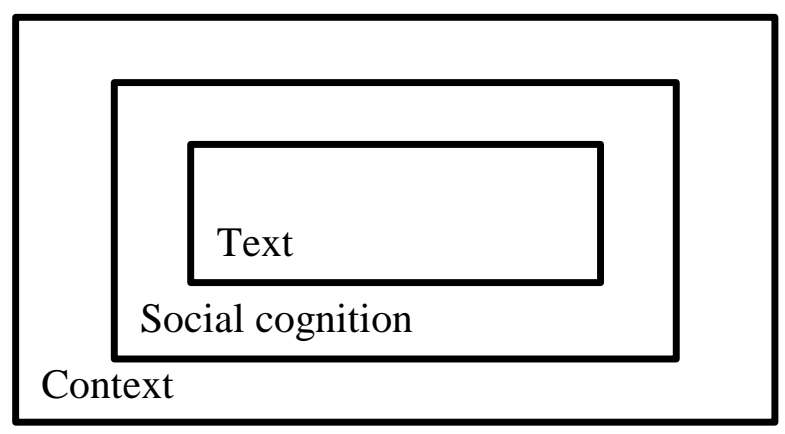

Image 1. van Dijk model analysis

Broadly, the text is a trace of speech; which can be realised in the form of verbal, linguistic, or non-verbal traces - or the form of gestural, sensory-perceptual or prosodic (Cornish, 2009). Text is also defined as all forms of language, not only words printed on sheets of paper, but also all types of communication expressions, speech, music, pictures, sound effects, images, and so on (Eriyanto, 2015). Although, earlier in the discussion of discourse definition is mentioned that the text and signs, or symbol (it could be images etc.) seem different, but the researchers underline, in the critical discourse analysis the text can be interpreted broadly which included in the text understanding from Cornish (2009) and Eriyanto (2015).

Van Dijk saw a text consisting of several structures or levels, which supported each other; macrostructure, superstructure, and microstructure (Eriyanto, 2015). Macrostructure is a global or general meaning that can be understood by looking at the topic of a text. The superstructure is the framework of 
a text; the structure and elements are arranged in a whole text. The microstructure is the meaning of a discourse that can be observed by analysing words, sentences, propositions, or clauses used. However, van Dijk claims that research on discourse is not enough based on text analysis, it must also be seen on how a text is produced, so it is known why writer creates or produced a text; this production process involves a process called social cognition.

Social cognition is a dimension that explains how texts are produced by individuals or groups (Eriyanto, 2015). How the writers or creators see a social reality influences the appearance of certain texts. Social cognition is related to the mental awareness of the writer who creates the text. van Dijk thinks that the text has no meaning, but it is given by the mental awareness process of the writer. The writer is not seen as a neutral individual, but an individual who has a variety of values, experiences, and ideological influence gained from his life. Thus, discussions in social cognitive include such as interpreting human interactions, drawing conclusions from verbal and unspoken communication, and developing an understanding of the dynamics of a group (Morgan, Joseph, \& Carley, 2018); which will reveal such as the ideology of the writer. This ideology is interpreted as the basis of social representation possessed by members of certain groups (van Dijk, 1998)

Van Dijk added that social cognition could be understood based on the scheme. Schemes are conceptualised as mental structures which include how we view humans, social roles, and events (Eriyanto, 2015). There are several types of schemes or models (Eriyanto, 2015):

1. Person scheme; describe how someone depicts and views others. For example, how Muslim journalists view and understand Christians will influence the news texts that he writes.

2. Self-scheme; related to how oneself is seen, understood and described by someone.

3. Role scheme; related to how someone views and describes the role and position occupied by someone in society.

4. Event scheme; this scheme is may the most widely used because everyday events are always seen and heard. Generally, this event scheme is the most widely used by journalists.

The last is the context. Context is very important in communication to understand the meaning. Thus, context can also be referred to as a conceptual framework that is used as a reference by the speaker or the listener to understand the speaker's purpose or meaning or a discourse (Saifudin, 2018). Context or in this study refers to the social context is a dimension to see how texts are related to social structures and knowledge that develop in society (Ningsih, Rusminto, \& Karomani, 2014). Besides, social context is also related to the speaker's social attributes, and it's setting (Saifudin, 2018). The study of context is necessary because context influences the production of discourse. Such as the political situation; especially the dynamics of the implementation of certain regional autonomy can affect the text produced. 
Thus, from that discussion, it can be concluded that the analysis of critical discourse is an analysis that is not only focused on the text but also cognition and social context. This is because a text is produced based on the perspective of the writer in seeing a reality. Moreover, the implementation of critical discourse analysis has completed by many researchers, such as research conducted by Humaidi (2016). He analysed the speech of Former fifth Indonesian President Susilo Bambang Yudhoyono. By following the theory of van Dijk or the van Dijk method, he reveals critically about the dimensions of the text, social cognition, and the social dimension of the speech of Mr. Susilo Bambang Yudhoyono.

The other research is conducted by Nurlaily (2018). she analysed the elements of sexuality in the novel of Pasung Jiwa by Okky Madasari. The purpose of this study is to reveal the existence of discrimination against the fate of women related to sexuality in society as represented in the novel Pasung Jiwa. This study uses a qualitative approach with the method of van Dijk. The results of this study show that the Pasung Jiwa novel is a novel created as a media of criticising about sexuality. Besides, the discourse of sexuality raised in the novel depicts efforts to marginalise women.

Discourse can be found anywhere, not only in novels or speeches. Discourse can also be found in skincare product packaging (Defi, 2018). The form of discourse in skincare packaging is used to increase the and selling price of the product, where the appearance of the packaging ranked on the third position in influencing the buyers' or consumers' consideration when choosing and buying a product; $25,6 \%$, besides to the price consideration; 79,5\%, and product brand; 53,8\% (Defi, 2018).

However, critical discourse analysis research on product packaging has not been done much, especially on skincare products. Based on the literature conducted by the researchers, there is not many studies or researches that critically analysing the discourse on product packaging. One of the researches that discuss critical analysis on product packaging is Defi (2018). In her research, she discusses the masculine figure in the Balm packaging critically by using the theory of van Dijk's critical discourse analysis. Even researches which discuss skincare product are not new issues anymore, but, those researches focused on the advertising (Afriani, 2012; Fauzi, 2018; Sidik, 2018; Siregar \& Butar, 2017).

From the discussion above, the researchers are interested in critically analysing the discourse in Pond's packaging. The researchers choose Pond's products because Pond's is one of the well-known and widely used skincare products. Pond's is a skincare brand that has various forms of products that can be used for women and men. According to the official website, this product has existed since the $18^{\text {th }}$ century; it can be said that Pond's experience in the field of skincare has been very long. Thus, the researchers are interested in analysing the Pond's product.

However, this research is different from the previous researches. The difference is in the focus of the analysis, where the previous researches are focused on identifying only from the advertisement or packaging physically, while this research focuses on the claims and the additional information contained in Pond's products packaging. This is because the results of the preliminary study conducted 
by the researchers, researchers found much additional information that is in a separate place or smaller font from the claim statement mentioned. This additional information usually explains various things such as terms, provisions, or other information related to the products' claims. However, additional information is not only found in Pond's products; but, the reason why the researchers choose Pond's as the focus data on this research is based on what discussed earlier. Thus, the results of this research can reveal critically the additional information written on Pond's products.

\section{RESEARCH METHOD}

This study uses a critical discourse analysis method, which refers to the Teun A. van Dijk analysis method. Concerning the three dimensions of analysis previously discussed, that are text, social cognition and social context. Data collection technique in this study is documentation. Researchers use the camera on the cellphones to collect the data. The data used in this study consisted of skincare products released by Pond's. The data obtained are then analyzed using threedimensional discourse analysis from van Dijk. Besides, researchers surveyed the users of skincare products; from the hundreds of skincare products users whose researchers know, only five are willing to become survey respondents. Meanwhile, the steps of the research are as follows.

1. Researchers look for data by collecting Pond's products by using a camera on the cellphone,

2. Researchers make observations by selecting and sorting Pond's products that have criteria that can answer the research objectives, the criteria of the product are having the additional information in the small font and separated or far from the claim text,

3. The selected product is then analyzed based on the dimensions of the text,

4. After interpreting at the level of the text, the researcher goes on to analyse the social dimension and social context, and

5. To strengthen the analysis, researchers add data obtained from the results of a survey conducted to skincare products users.

\section{RESULT AND DISCUSSION}

After doing observations on December 23, 2019, the researchers found some data on skincare products following the research objectives. These products are available in the Table 1. 
Table 1. Data of The Study

\begin{tabular}{|c|c|c|}
\hline \multirow{2}{*}{ No. } & \multicolumn{2}{|r|}{ Product } \\
\hline & Name & Varian \\
\hline 1. & Pond's Age Miracle & a. Ultimate youthful glow \\
\hline 2. & Pond's Vitamin Micellar Water & a. D-TOXX charcoal \\
\hline \multirow[t]{5}{*}{3.} & Pond's White Beauty & $\begin{array}{l}\text { a. Instabright tone up milk cream SPF } 30 \\
\text { PA++ }\end{array}$ \\
\hline & & $\begin{array}{l}\text { b. Instabright tone up milk mask with } \\
\text { plankton }\end{array}$ \\
\hline & & c. Spot-less glow facial foam \\
\hline & & d. Mineral clay mask \\
\hline & & $\begin{array}{l}\text { e. Spotless rosy white day cream normal } \\
\text { skin }\end{array}$ \\
\hline
\end{tabular}

The data from Table 1 is obtained from observations at a store. Researchers found many data but only use three Pond's products with various variants included in the research category, so all products included in the research category are seven products. Researchers believe more products have been produced by Pond's. However, to limit that very large number, the research only focused on products that are found from observations at a store. It is because the additional information referred to this article has been contained and represented in the product in Table 1. From the products in Table 1, researchers found that the discourse contained in these products is very diverse. The Table 2 shows the claims and additional information obtained from the observation of Pond's products in Table 1.

There are two kinds of information that the researchers get from Table 1; the researchers found many of claim and the additional information (in table 2). Additional information in this study refers to the text that following the claims. The claim and additional information in the products as in table 2 are parts of the text. In the previous discussion mentioned that text could be a form of music, pictures, sound effects, images. However, the text that the researchers used as the study in this research is in the form of a sentence or phrase. Thus, this text is be defined as a language construction from unit words to discourse (Rahmawati, 2016), and the dimensions of the text under study are the structure of the text in which there is linguistic analysis (Ningsih et al., 2014).

Van Dijk discusses the critical discourse analysis is not only to the text. It is because the analysis of critical discourse, as explained earlier, is a discussion that reveals the things behind the text. Thus, when the discussion only leads to text analysis activities, the discussion does not lead to the concept of critical discourse analysis. In case, van Dijk put another concept of critical discourse analysis that is social cognition, and social context. 
Table 2. Claims and Additional Information

\begin{tabular}{|c|c|c|c|}
\hline \multicolumn{2}{|c|}{$\begin{array}{l}\text { Product } \\
\text { codes and } \\
\text { variants }\end{array}$} & \multirow[t]{2}{*}{ Claim } & \multirow{2}{*}{$\begin{array}{l}\text { Additional Information } \\
\text { Berdasarkan uji klinis. Pemakaian } \\
\text { teratur krim pagi dan serum - } \\
\text { translated "Based on clinical } \\
\text { test. Regular use of morning } \\
\text { cream and serum" }\end{array}$} \\
\hline 1. & a. & & \\
\hline \multirow[t]{2}{*}{2.} & a. & $\begin{array}{l}\text { UP TO 99\% MAKE-UP REMOVAL - } \\
\text { translated “UP TO 99\% MAKE UP } \\
\text { REMOVAL" }\end{array}$ & $\begin{array}{l}\text { Berdasarkan uji klinis, bergantung } \\
\text { pada tipe dan intensitas - } \\
\text { translated "Based on clinical } \\
\text { test, depends on skin type and } \\
\text { intensity of use." }\end{array}$ \\
\hline & & $\begin{array}{l}\text { Micellar water pertama dengan vitamin } \\
\text { dan rose - translated "First Micellar } \\
\text { Water with vitamin and rose" }\end{array}$ & $\begin{array}{l}\text { Dari Pond's - translated "From } \\
\text { Pond's" }\end{array}$ \\
\hline \multirow[t]{5}{*}{3.} & a. & $\begin{array}{l}\text { Tone up cream pertama - translated } \\
\text { "The first tone up cream" }\end{array}$ & $\begin{array}{l}\text { Dari Pond's - translated "From } \\
\text { Pond's" }\end{array}$ \\
\hline & b. & $\begin{array}{l}\text { Kulit tampak cerah - translated } \\
\text { "Brighter looks skin" }\end{array}$ & $\begin{array}{l}\text { Kulit tampak cerah natural ketika } \\
\text { digunakan setiap hari. Hasil } \\
\text { bergantung pada kondisi kulit } \\
\text { masing-masing - translated "Skin } \\
\text { looks natural brighter with } \\
\text { regular use. The result may } \\
\text { depend on skin condition" }\end{array}$ \\
\hline & c. & Pond's most advance cleanser & $\begin{array}{l}\text { Compared to other Pond's } \\
\text { cleansers in the market }\end{array}$ \\
\hline & d. & $\begin{array}{l}\text { Diformulasikan khusus dengan } 100 \% \\
\text { Moroccan Clay alami yang diperkaya } \\
\text { kandungan mineral untuk mengikat } \\
\text { kotoran lebih baik - translated } \\
\text { "Formulated with 100\% natural } \\
\text { Moroccan Clay which enrich with } \\
\text { mineral to bind impurities better" }\end{array}$ & $\begin{array}{l}4 \text { kali lebih dari charcoal biasa, } \\
\text { berdasarkan uji in vitro - } \\
\text { translated " } 4 \text { times more than } \\
\text { ordinary charcoal, based on in } \\
\text { vitro test" }\end{array}$ \\
\hline & e. & $\begin{array}{l}\text { Double Whitening Formula dengan } \\
\text { Advanced Vitamin B3+ membantu } \\
\text { mencerahkan kulit DARI DALAM - } \\
\text { translated "Double Whitening Fromula } \\
\text { Advanced with Vitamin B3+ which helps } \\
\text { to brighten skin FROM INSIDE" }\end{array}$ & $\begin{array}{l}\text { Lapisan epidermis - translated } \\
\text { "Epidermal layer" }\end{array}$ \\
\hline
\end{tabular}




\section{Text}

Thus, text can be defined as a language construction from unit words to discourse (Rahmawati, 2016). The dimensions of the text under study are the structure of the text in which there is linguistic analysis (Ningsih et al., 2014). Text analysis, as expressed by van Dijk is divided into three structures that are macrostructure, superstructure, and microstructure (Eriyanto, 2015). Below is the discussion.

\section{a. Macrostructure}

Skincare products are products sought by women and men. The claims are written aimed to showing the advantages of their products. Such as the Pond's products which also display various advantages that aimed to attract buyers' interest in choosing their product or variant. Besides, there is also additional information that serves as a further statement or information about the claims (Table 2). This additional information is generally interpreted as supporting statements of the claim (code: $1 a, 2 a, 3 a, 3 b, 3 c, 3 d$, and $3 e$ ) that support the text of claims and suggestions (code: $1 a$, and $3 b$ ) that the user needs to do, to get better results. This all claims and additional information act as the element of the promotion, which this element have the role as information and advice needed, persuade the customers and remind the buyer to buy in the right time (Kartawinata \& Wardhana, 2013). However, the role of reminding the buyer to buy in the right time does not find in the data.

\section{b. Super Structure}

In creating texts on Pond's products, the company always start with claims that say the superiority of their products. Then, the claim is followed by a symbol (* or $\wedge^{\wedge}$ ) which leads to additional information. This additional information in the macrostructure discussion interpreted as an element that has the role of the supporting statements or advice that must be done by the users or buyers to get maximum results. Below is the example of the use of symbols on Pond's products that lead to additional information from the text of the claims.
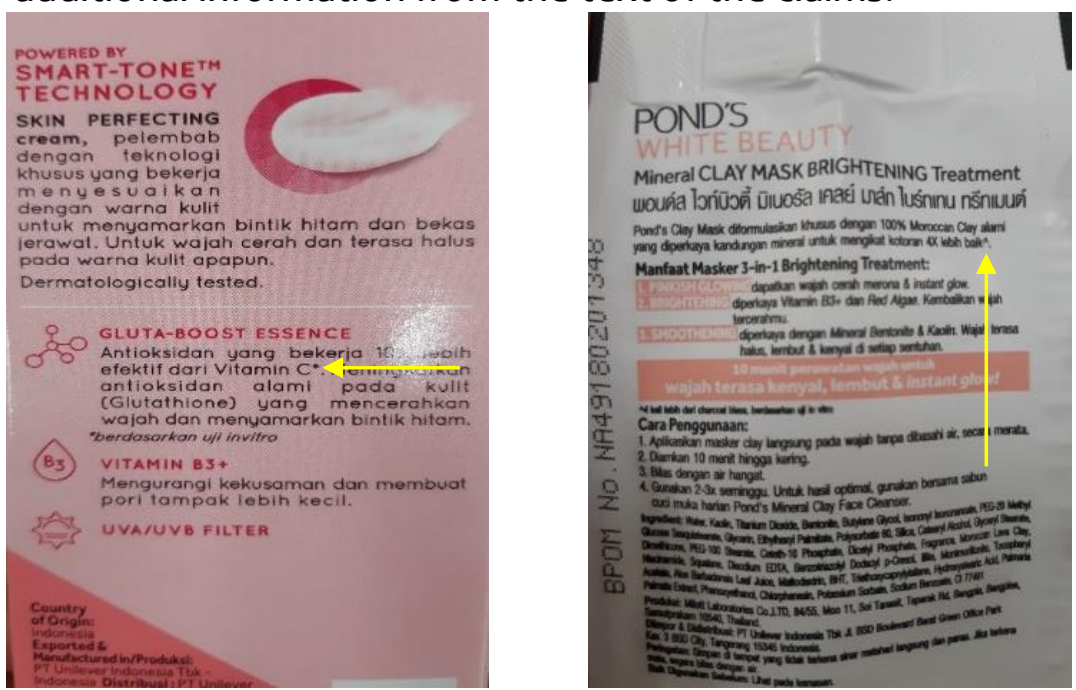

Image 2. The Use of Symbols on Pond's Products 


\section{c. Microstructure}

This section focuses on discourse at a smaller level, such as words, phrases, clauses, or sentences. The discussion of this section is as follows.

\section{1) Semantic}

This section discusses the meaning of emphasized in Pond's products. Overall the meaning that is emphasized in each product is divided into two; the meaning of the claim that aims to attract buyers and the meaning of additional information that aims to support the claims or suggestions that need to be done by the buyers or users. The following is the semantic analysis of the products in Table 2.

The meaning on the claim of code 1 a refers to an assumption or claim that "Pond's Age Miracle: Ultimate Youthful Glow" is a product that has benefits three times faster as the skincare. The text is supported by the additional information that they produce this claim is based on clinical test results. However, to get the claimed results, the users or buyers need to use Pond's Age Miracle Ultimate Youthful Glow product regularly added with the application of additional serum.

The meaning on the claim of code $2 a$ means that "Pond's Vitamin Micellar Water: D-TOXX charcoal" is a product that contains $99 \%$ ingredients which can remove makeup. Besides, it is also the first product that uses vitamins and rose. However, additional information available states that the removal power of makeup depends on the type and intensity of use of make-up; and this result is based on the clinical test. Besides, the meaning of the word "first" that use vitamins and rose is the first product from Pond's.

The meaning on the claim of code 3 a means that "Pond's White Beauty: Instabright tone up milk cream SPF $30 \mathrm{PA}++$ " is the first tone up cream product. However, just like the previous discussion, the word "first" in this product is also the first product from Pond's. The meaning on the claim of code $3 \mathrm{~b}$ means that with the use of "Pond's White Beauty: Instabright tone up milk wash with plankton" can make the users get brighter skin. Even though, on the additional information stated that the word "cerah - translated as brighter" refers to the natural brightness that is obtained by using the product regularly in daily use. Then, the result can be different; each user depends on the users' skin.

The meaning on the claim of code $3 c$ means that "Pond's White Beauty: Spot-Less Glow" is a cleaning product that has a very quickly power in cleaning the skin. However, the additional information stated that the claim is compared to the other Pond's products. The meaning on the claim 3d means that "Pond's White Beauty: Mineral clay mask" made by natural ingredients with 100\% Moroccan Clay, which contains mineral and has better benefits in bind the impurities. However, in the additional information stated, this claim is based on in vitro test on ordinary charcoal.

The meaning on the claim of code ze means that "Pond's White Beauty: Spotless rosy white day cream normal skin" contains the double whitening formula that helps to whiten the skin from the inside; the formula is advanced with vitamin 
$\mathrm{B}+$. On the other hand, the additional information written shows that the inside means from the epidermis layer.

\section{2) Lexicon}

This section discusses the choice of words or phrases used by the writer or company to express their opinions. The choice of words used in each claim and additional information in Table 2 can indicate the company's desired goals. In this case, the researchers choose words which indicate have a specific purpose, the words are written on Pond's claim which consists of; $3 x$ lebih cepat (code: 1a), pertama (code: $2 a$ and 3a), percentages 99\% and 100\% (code: $2 a, 3 e$ ), tampak cerah (code: $3 b$ ), most advance (code: $3 c$ ), advance (code: $3 e$ ), and dari dalam (code: $3 e$ ). Researchers only focused on text claims because this text is the main highlighted by the company rather than additional information. Below is the following explanation:

Table 3. Lexicon Analysis

\begin{tabular}{|c|c|}
\hline $\begin{array}{l}\text { Word or } \\
\text { phrase }\end{array}$ & Aims \\
\hline $\begin{array}{l}3 X \quad \text { lebih } \\
\text { capat } \\
\text { translated } \\
\text { " } 3 \times \text { faster" }\end{array}$ & $\begin{array}{l}\text { The use of the word " } 3 x \text { lebih cepat" aims to make buyers } \\
\text { interested in trying the products they made because they claim } \\
\text { that users will get benefits; } 3 \text { times faster. }\end{array}$ \\
\hline $\begin{array}{l}\text { Pertama - } \\
\text { translated } \\
\text { "first" }\end{array}$ & $\begin{array}{l}\text { The use of the word "Pertama" aims to inform buyers that the } \\
\text { product they made is the first product with certain benefits. }\end{array}$ \\
\hline $\begin{array}{l}\text { Percentage } \\
99 \% \quad \text { and } \\
100 \%\end{array}$ & $\begin{array}{l}\text { The use of a percentage is intended to notify buyers if the products } \\
\text { made by Pond's uses much of composition for skincare; so, the } \\
\text { users will get so much better benefits. }\end{array}$ \\
\hline $\begin{array}{l}\text { Tampak } \\
\text { cerah } \\
\text { translated } \\
\text { "look } \\
\text { brighter" }\end{array}$ & $\begin{array}{l}\text { The use of the word "tampak cerah" aims to make consumers } \\
\text { interested in trying the products because they promise that users } \\
\text { will get a brighter skin benefit. }\end{array}$ \\
\hline $\begin{array}{l}\text { Most } \\
\text { advance }\end{array}$ & $\begin{array}{l}\text { The use of the most advanced word in English, if interpreted in } \\
\text { Indonesian can have a variety of meanings, it aims to highlight } \\
\text { their products is the very best. }\end{array}$ \\
\hline Advance & $\begin{array}{l}\text { The use of the word advance in English, if interpreted in Indonesian } \\
\text { can have various meanings, aims to highlight their products is the } \\
\text { best. }\end{array}$ \\
\hline $\begin{array}{l}\text { Dari dalam - } \\
\text { translated } \\
\text { "from the } \\
\text { inside" }\end{array}$ & $\begin{array}{l}\text { The use of the word "dari dalam" aims to inform consumers that } \\
\text { Pond's products work from the inside of the skin. }\end{array}$ \\
\hline
\end{tabular}




\section{3) Syntaxes}

The discussion in this section examines at the level of sentence or phrase structure. The text in Pond's product is composed of various phrases. The phrase is a union of a small group of words that forms a meaning in a clause (Spasic, BabicAntic, \& Spasic-Stojkovic, 2015). Phrases consist of various types; noun phrases, verb phrases, numeral phrases, adjective phrases, adverb phrases and prepositional phrases (Supriyadi, 2014). The often emerge phrases in Pond's products in Table 2 are the adjective phrase and the adverb phrase. An adjective phrase is a phrase that has an adjective as the head. Below is an example.

Code 1a - $3 x$ lebih cepat translated " $3 x$ faster."

"Cepat" or "Fast" is an adjective that is head in this phrase. The word "Cepat" in this context describes something that can be obtained immediately. Then for the adverb phrase, the example is as follows.

\section{Code 2a dan $3 a$ - Dari Pond's}

The word "Pond's" is a description that indicates the origin or company. The word "Pond's" in this phrase forms the meaning produced by Pond's.

\section{4) Rhetoric}

Rhetorical element is an element that discusses the style that emphasises a particular topic in a text (Imam, 2012). The style has a strong relationship with how a message is conveyed. The style of language used by Pond's company aims to attract buyers. The style emphasised in the text in claims of Pond's product is the hyperbole language style. Manufacturers over-describe the benefits of their products. The following are some examples of the texts.

\section{Code 1a - 3x lebih cepat translated " $3 x$ faster."}

\section{Code $3 d$ - Pond's most advance cleanser}

The sample text above is written to show the superiority of Pond's products. The text is identified as having a hyperbole force marked by the phrases " $3 x$ faster" and "most advance cleanser". This phrase shows that Pond's product has extraordinary benefits, so in other words, their product is the best or has a better advantage than other products. However, if referring to additional information from the phrase " $3 x$ faster" obtained from the results of the clinical test that is conducted with the application of morning cream and serum. While the phrase "Pond's most advance cleanser" is compared to other Pond's products.

\section{Social Cognition}

Social cognition is related to how a text is written (Ningsih et al., 2014). It becomes one of the determining factors in the writing direction (Ningsih et al., 2014). Thus, from this discussion, the researchers will reveal the ideology of the author or in this article is the Pond's company in creating the text. Ideology, as mentioned before defined as the basis of social representation possessed by certain groups. This means that ideology allows people, as members of groups, to organise many social beliefs about what is happening, good or bad, right or wrong, for them, and to act accordingly (van Dijk, 1998). 
Text written in printed or electronic form can describe the author's ideology, including text in the Pond's products. From the products in Table 2, the researchers found various claims that are added with additional information that referred to the suggestion or reinforcement statement. Overall, the text of the claims on the product can be interpreted as an effort made by the company to highlight the product. Through these claims, the company try to accentuate their products and obscure deficiencies by adding additional information in the text of the claims. This is evidenced by the additional information text that is written with the separate and small size (compared with the claims). Below are the examples.

Evidence 1

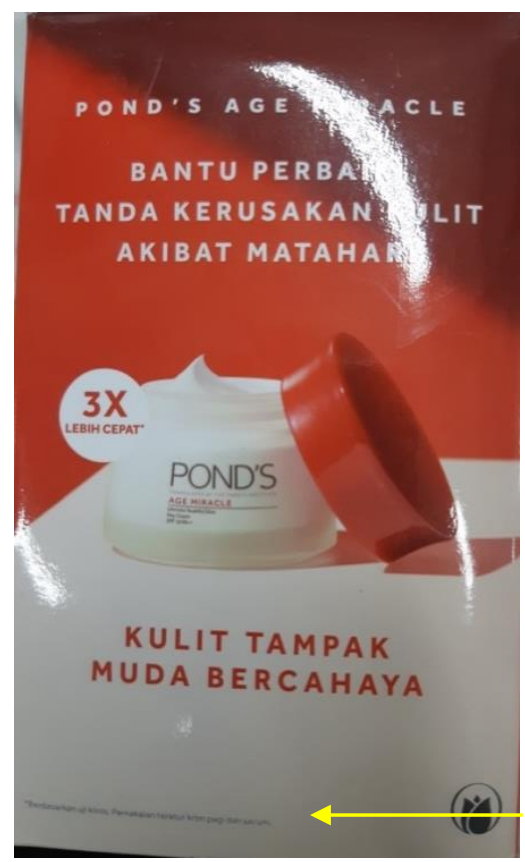

Evidence 2

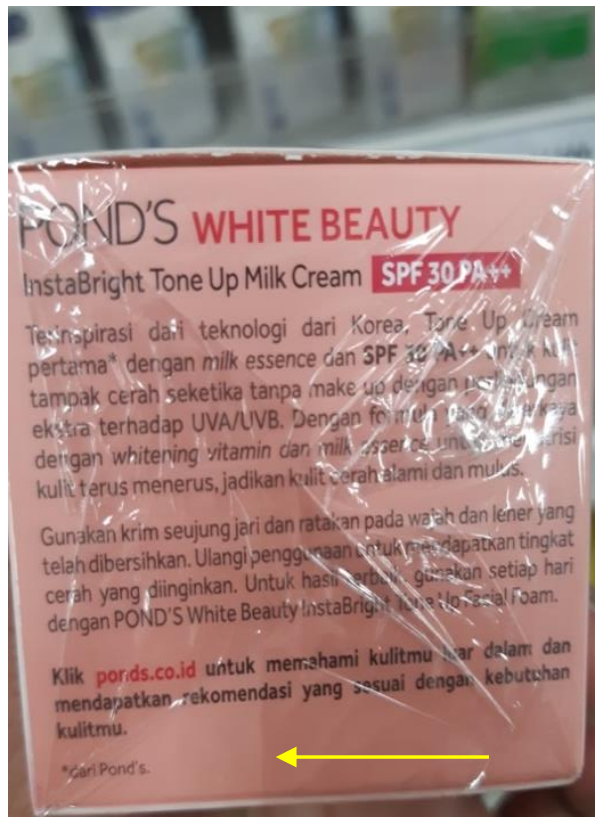

Image 3. Small Additional Information

This small text is difficult to read, especially for someone who has an eye problem. This small font size is included in the aspect that can affect the level of readability of a text (Adi, 2018). Thus, if the size of the written text is much smaller, then it will affect the level of readability or not readable (Rello, Pielot, \& Marcos, 2016). Besides, the additional text is located at the end of the product packaging and far from the claim text. The use of separate additional information can also affect consumers' understanding. It is consistent with the research that mentions, space can affect the level of readers' understanding (Rello et al., 2016). The space referred in this study is the space between lines, so it can be concluded that if the space between lines can make readers less understanding, the placement of additional information located far or separately from the claim text can also affect the buyers' understanding. Thus, the large text (which in this study stated as claims or advantages) will be the main focus or readable by the readers or buyers. 
In the first evidence (Image 3 ) it is seen that " $3 x$ faster" is the result of a test with regular use together with morning cream and serum. Thus, it is not true that only using this product (Image 3 evidence 1 ) can make the skin look young and glow three times faster.

In the second evidence (Image 3) also not different from the first evidence, the company writes the claim then add with the additional information. The claim "Tone Up cream pertama" translated "The first tone up cream" then the additional information is written "dari Pond's" translated "from Pond's". The two texts are separated in a distant position, whereas this text can be written after the claim. However, the company prefers to make additional information separated from the text of the claims. Besides, the statement is written in a smaller size than the text size of the claim. Thus, when the buyer reads the whole text (claim and additional information), it is not true that the "pertama" translated "first" meaning, that is emphasised in this claim is the originator from all types of skincare products, however, the first product produced by Pond's.

Beside of small-text information, there is also additional information that has the same font size. An example is in the following picture.

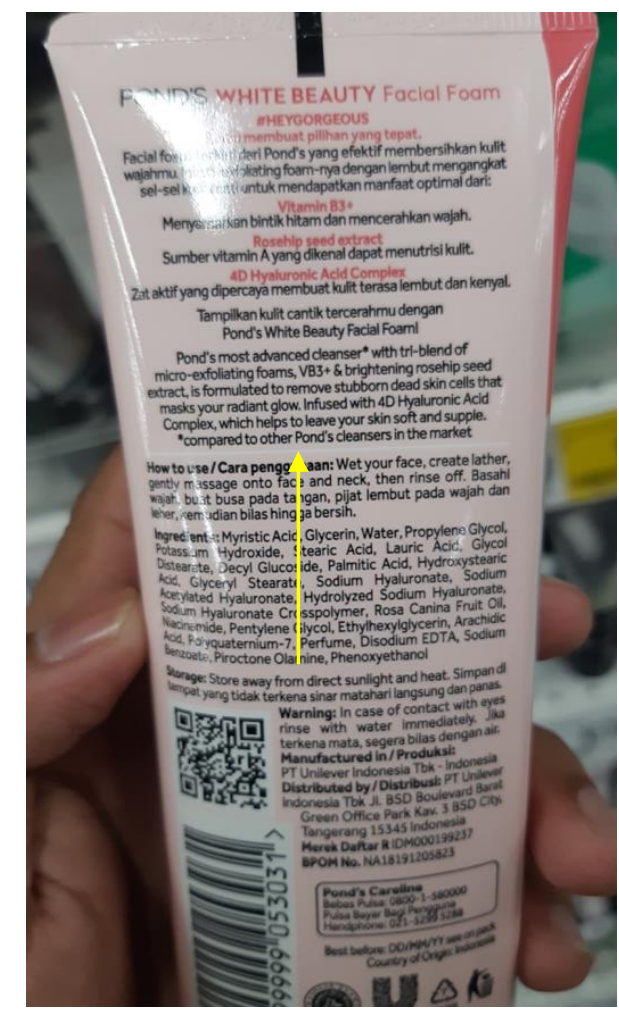

Image 4. Another Additional Information

In the first evidence (Figure 4), the claim and additional information text are at the same size (font). However, the two texts are separated, the text which explains the superiority, written as "Pond's most advance cleanser" and the additional information text "compared to other Pond's cleansers in the market". Similar to the previous discussion, the company seemed to distance the fact that 
the meaning of most advance cleanser as compared to their product (Pond's product).

These three examples can be interpreted that the company try to blur the deficiencies of their products (Pond's product in Table 1). Blurring in this article means, it does not show clearly the additional information in the products available in table 1 (evidence: Image 3 and Image 4). If the additional information is written has the same strength as the claim (same size or same font and has not distanced), it will affect the consumers to buy. This is because the consumers will be more careful using their money to buy products that suit their needs (Harianto, 2008). Thus, they try not to show clearly what buyers or users have to do to get maximum results (evidence 1 Figure 3 ) because the additional information can reduce the meaning of excellence over from the claims. Besides, they also seemed to obscure the fact, that the claims they made are compared to their products (proof 2 Figure 3 and proof 1 Figure 4). They highlight the advantages that will increase sales. Thus, it can conclude that the marketing technique from the Pond's company (on the product in Table 1) is by blurring the facts that aim to obscure the real reality.

\section{Social Context}

The social context, as discussed earlier, discusses how the text is related to the social structure and knowledge that develops in society (Ningsih et al., 2014). In the previous discussion, researchers have analysed the ideology of the text writer (company). In this discussion, the researchers will discuss how the social context (society or buyer) influences the production of the text.

Skincare products are in great demand by women and men. Someone who wants to have healthy skin will try to treat it well. Leather or packaging of the products on the market always show their advantages. No company advertises its products with do not use a claim that the products give any benefits to the users. They always highlight the advantages of the products being marketed.

According to a survey conducted by researchers, five from five users of skincare products said that they always look at the benefits offered by skincare products before buying. The benefits refer to the claims offered by the company of skincare. One of the users added that the product that she buys is something needed. Thus, if she wants a product about acne, then the product she bought is a product that has these benefits.

From this basis, the researchers assume that the claims written in skincare products are used to answer consumer desires. Including Pond's company; in the previous discussion is using hyperbole language in marketing their products. It is used to make the buyers choose the products that are produced by Pond's rather than those produced by other brands. Thus, Pond's company creates a small and separate additional information on the products in Table 2 to obscure the real facts of the claims made. This step is a marketing technique that is used to market Pond's products listed in Table 1 . It is consistent with research that reveals; product packaging is part of the marketing techniques carried out by companies to increase sales (Ghahnavieh, 2018). 


\section{CONCLUSION}

The results of this research reveal something different from the previous researches. Besides, the apparent novelty is on the focus of research that critically reveals additional information from claims on Pond's products. Researchers have not found similar research that analyses this area. From the results of the analysis, researchers found the purpose of using additional information that refers to claims, where additional information is small and located separately. Besides, researchers in this research also revealed the ideology of the discourse maker (Pond's company) in marketing their products in Table 1. Researchers refer to van Dijk's theory to conduct the discussion. There are three dimensions analysed namely; text, social cognition and social context. The following are the conclusions from the results obtained by the researchers.

Discussion on the text is divided into three; macrostructure, superstructure, and microstructure. In the macrostructure, in general, the meaning contained in the claims written in Pond's products aims to attract consumers. Then, additional information becomes a support for the written claim, but also as a suggestion that needs to be done by the user to get better results. In the superstructure, the company always starts with claims that increase the superiority of their products. Then, the claim is followed by a symbol $(*$ or $\wedge$ ) which leads to additional information. In the microstructure, the company uses a strategy that highlights the superiority of the products produced.

Social cognition discusses the ideology of Pond's company. In this discussion, the company only highlight the excellence of their product. They use additional information (which should explain more clearly about claims of superiority) in lowercase or have a separated position from the claims' text. This additional statement is a statement that explains something different from the written claim. Thus, the marketing technique applied by writing additional information in small and separate sizes aims to obscure the real facts of the claims made.

The last, the social context discusses how the social (society or buyer) influences the production of texts in Pond's products. Claims written in Pond's products are used to answer the society or buyer desires; where five from five users of skincare products mention that, they always look at the benefits offered before buying. Thus, claims written on the product are used to make the consumers choose Pond's products.

\section{REFERENCES}

Adi, N. W. (2018). Tingkat keterbacaan huruf pada rambu petunjuk jurusan di Jakarta. JSRW (Jurnal Senirupa Warna), 6(2), 175-185.

Afriani, S. H. (2012). ISLAMIC BEAUTY: Socio-Semiotic Analysis of Facial Foam and Body Lotion Advertisement. JOURNAL OF INDONESIAN ISLAM, 6(2), 265-278.

Cornish, F. (2009). "Text" and "discourse" as "context": Discourse anaphora and the FDG Contextual component. Working Papers in Functional Discourse Grammar (WP-FDG-82) The London Papers I, 1(1), 97-115. Retrieved from https://hal-univ-tlse2.archives-ouvertes.fr/hal-oog61139/document

Darma, Y. A. (2009). Analisis wacana kritis. Bandung: YRAMA WIDYA. 
Defi, Z. (2018). Kajian maskulinitas pada kemasan kosmetik (analisis wacana kritis terhadap kemasan produk kosmetik theBalm) (Institut Seni Indonesia Yogyakart). Retrieved from http://digilib.isi.ac.id/4169/1/bab i.pdf

Eriyanto. (2015). Analisis wacan: pengantar analisis teks media. Yogyakarta: LKIS.

Fauzi, A. (2018). Discourse analysis of pond's men's advertising "lelakimasakini" version of Rio Dewanto. Capture : Jurnal Seni Media Rekam, 9(2), 15.

Ghahnavieh, A. E. (2018). The Influence of Marketing Factors on the Marketing Strategic Planning in SNOWA Corporation. Business and Management Studies, 4(4), 52-61. https://doi.org/10.11114/bms.v4i4.3133

Harianto, D. (2008). Standar penentuan informasi iklan menyesatkan. Jurnal Equality, 13(1), 41-49.

Humaidi, A. (2016). Struktur Teks, Kognisi Sosial, Dan Dimensi Sosial Pidato Susilo Bambang Yudhoyono (Text Structure, Social Cognition, And Social Dimension Susilo Bambang Yudhoyono's Speech). JURNAL BAHASA, SATRA, DAN PEMBELAJARANNYA, 6(1), 115-127.

Imam, A. F. (2012). Analisis wacana Van Dijk pada lirik lagu Irgaa Tani (my heart will go on). Journal of Arabic Learning and Teaching, 1(1), 1-8.

Kartawinata, B. R., \& Wardhana, A. (2013). Marketing strategies and their impact on marketing performance of the Indonesian ship classification society. International Journal of Science and Research, 4(2), 69-74.

Morgan, G. P., Joseph, K., \& Carley, K. M. (2018). The power of social cognition. Journal of Social Structure, 18, 1-22.

Ningsih, D. R., Rusminto, N. E., \& Karomani. (2014). Teks, konteks, dan kognisi sosial wacana bertema pendidikan dalam kompasiana dan implikasinya. J-SIMBOL (Bahasa, Sastra, Dan Pembelajarannya), 2(1), 1-9.

Nurlaily, A. S. (2018). Unsur seksualitas yang direpresentasikan tokoh novel pasung jiwa karya Okky Madasari: analisis wacana kritis Teun A. Van Dijk. METASASTRA: Jurnal Penelitian Sastra, 11(2), 145-156. https://doi.org/10.26610/metasastra.2018.v11i2.145-156

Rahmawati, I. Y. (2016). Analisis teks dan konteks pada kolom opini "Latihan Bersama Al Komodo 2014" Kompas. Jurnal Dimensi Pendidikan Dan Pembelajaran, 4(1), 49-57. https://doi.org/10.24269/dpp.v4i1.53

Rello, L., Pielot, M., \& Marcos, M.-C. (2016). Make It Big! Proceedings of the $2016 \mathrm{CHI}$ Conference on Human Factors in Computing Systems, 3637-3648. https://doi.org/10.1145/2858036.2858204

Saifudin, A. (2018). Konteks dalam Studi Linguistik Pragmatik. Lite: Jurnal Bahasa, Sastra, Dan Budaya, 14(2), 108-117.

Schiffrin, D., Tannen, D., \& Hamilton, H. E. (Eds.). (2001). The handbook of discourse analysis. Hong Kong: Blackwell Publishers.

Sidik, A. (2018). Analisis iklan produk shampoo Pantene menggunakan teori Semiotika Pierce. Technologia: Jurnal Ilmiah, 9(4), 201. https://doi.org/10.31602/tji.v9i4.1533

Siregar, A. L., \& Butar, M. L. E. F. B. (2017). A critical discourse analysis on Wardah halal beauty advertisements. Proceedings of The 2nd Annual International Seminar on Transformative Education and Educational Leadership (AISTEEL), 
229-231.

Spasic, D., Babic-Antic, J., \& Spasic-Stojkovic, M. (2015). Adverb or adverbial phrases: Structure, meaning, function. Zbornik Radova Uciteljskog Fakulteta PrizrenLeposavic, (9), 177-191. https://doi.org/10.5937/zrufpl1509177S

Supriyadi. (2014). SIntaksis Bahasa Indonesia. Gorontalo: UNG Press.

van Dijk, T. A. (1993). Principles of critical discourse analysis. Discourse \& Society, 4(2), 249-283. https://doi.org/10.1177/0957926593004002006

van Dijk, T. A. (1998). Ideology: A multidisciplinary approach. Wiltshire: SAGE Publications Inc. 